\title{
Abbreviations and conventions
}

In references to Wittgenstein's philosophy, I have followed the convention of using the initials of the work concerned followed by the number of the aphorism $(P I \S=$ Philosophical Investigations; OC $\S=$ On Certainty; TLP $\S=$ Tractatus Logico-Philosophicus).

Where I have used a text in an original language that I read, I have provided the original language version, along with my own translation. I have not done so with texts in German, but have relied there on existing translations. While, for the most part, I have sought to confine this monograph to languages that I know, I concluded that the subject matter of the study - the integration of the Hispanic with some key canonical writers for 'modernity' demanded the inclusion of Nietzsche and Marx.

With the proliferation of e-publishing, many books are now habitually read and accessed in digital form. I have used the Kindle referencing system of locations in the form: loc.x. 
Andrew Ginger - 9781526147851 Downloaded from manchesterhive.com at $04 / 26 / 2023$ 02:25:35PM via free access 